\title{
Management Alternatives for Pratylenchus brachyurusin the Soybean Crop
}

\author{
Deucleiton Jardim Amorim ${ }^{1}$, Antonio Gabriel da Costa Ferreira ${ }^{1}$, Kessia Tenorio Figueirinha ${ }^{1}$, \\ Lusiane de Sousa Ferreira ${ }^{1}$, José Roberto Brito Freitas ${ }^{1}$, Edmilson Igor Bernardo Almeida ${ }^{1}$, \\ Francisca Frenna Verezza Rodrigues de Amorim ${ }^{2}$, Hellen Patricia Dantas Deifeld ${ }^{1}$, Izumy Pinheiro Doihara ${ }^{1}$ \\ \& Washinton da Silva Sousa ${ }^{1}$ \\ ${ }^{1}$ Department of Agronomy, University Federal of Maranhão, Maranhão, Brazil \\ ${ }^{2}$ Department of Agronomy, University Federal of Ceará, Ceará, Brazil \\ Correspondence: Deucleiton Jardim Amorim, University Federal of Maranhão, KM 04, s/nº-Boa Vista, CEP \\ 65500-000, Chapadinha, MA, Brazil. Tel: 559-899-172-2342. E-mail: deucleitonamorim@hotmail.com
}

Received: November 7, 2018

Accepted: February 1, 2019

Online Published: March 15, 2019

doi:10.5539/jas.v11n4p333

URL: https://doi.org/10.5539/jas.v11n4p333

\begin{abstract}
In the Maranhão cerrado, Pratylenchus brachyurus phytonematoid is present in soybean plantation areas, occurring significant losses. At this aspect, the aim was to evaluate the effect of crop succession in the reduction of population and damage of $P$. brachyurus on soybean. Treatments consisted of soybean cultivation on soybean (T1, control) and soybean cultivated in succession on the "straw" of Crotalaria ochroleuca (T2), C. spectabilis + millet 'ADR 300' (T3), millet 'ADR 300' T4), Brachiaria ruziziensis (T5), maize 'GNZ 2005' + B. ruziziensis (T6) and maize 'GNZ 2005' (T7). The following characteristics were evaluated: P. brachyurus infestation in soil and plant height, plant height, productivity, number of plants per plot, number of pods per $\mathrm{m}^{2}$, number of pods per plant, number of grains per plant, number of grains per pod, mass of a thousand grains, total mass and dry matter The highest populations of $P$. brachyurus have been found in conventional soybean cultivation on soybean, or when grown on maize straw 'GNZ 2005', B. ruziziensis and maize 'GNZ 2005' + B. ruziziensis. In turn, small populations of phytonematoid occurred in the succession of the soybean with $C$. ochroleuca, millet 'ADR 300' and systems consortium of these two cultures. In order to improve soybean yield in the Maranhão cerrado, it is recommended to use $C$. spectabilis during the off-season, as an option to reduce the population of $P$. brachyurus, as well as in the intercropped intercrop with 'ADR 300' millet and on its single crop.
\end{abstract}

Keywords: Glycine max, growth, maranhão, productivity, succession

\section{Introduction}

The Pratylenchus brachyurus has a natural occurrence in the Brazilian Scrubland and is considered the nematoide of the radicular injuries (Vilela et al., 2011; Machado et al., 2007). This species causes softening and/or degradation in the cell wall of the host, with suppression and reduction of its defense mechanisms, in order to generate complex feeding structures (Haegeman et al., 2012). Poor root growth is reflected in the low increment of aerial part of the plant, with reduction in the crop productivity. The visual symptomatology of the attack is made through field observations, in which it is possible to note "spots" of of plants with nutritional deficiency (chlorotic leaves), among other larger plants that do not present visual symptoms of nutrient deficiency (Barbosa, 2013).

In soybean producing areas, in the State of Maranhão, this nematode is also present (Freitas et al., 2017), similar to what occurs in other Cerrado's producing regions, that begin to show significant losses due to the high populations of $P$. brachyurus. These high economic damages in the soybean crop can cause productivity losses of up to $50 \%$ (Franchini et al., 2011).

P. brachyurus is a migratory, endoparasitic and polyphagus phytonematoid, that due to feeding, movement and injection of toxins inside the tissues, cause damages in soybean roots. The expansion of soybean in areas of sandy soils, combined with the use of susceptible cultivars and the sowing of host plant species such as maize, in the soybean off- season period, are the factors that have better explain the increase in the importance of the phytonematoid to the crop (Goulart et al., 2013). 
Cultural management, through succession or crop rotation, has been shown as the best tool for the control of $P$. brachyurus, due to the unavailability of resistant soybean cultivars and the inconsistency of results obtained with the use of nematicides.

Works performed in greenhouse has shown relevant results, in relation to the ability to multiply P. brachyurus by different plant species (Inomoto, 2011; Queiróz et al., 2014). This works had good results with Crotalaria spectabilis. There is also the use of some pearl millet genotypes (Pennisetum americanum L.), considered as unfavorable hosts. However, most part of maize hybrids (Zea mays L.) are considered favourable host to the phytonematoid.

It is important to note that few studies have been carried out in field conditions, therefore, different results can be found when compared to greenhouse essays. In the latter case, the environmental, edaphic and pluviometric variables that can interact on the yield of the crops and the population of these phytonematoids in a positive or negative way are not taken into account (Costa et al., 2014).

Due to the importance of soybean cultivation, the damage caused by P. brachyurus to the crop and the probable efficacy of cultural practices to eradicate or mitigate these problems, it is necessary to analyze management alternatives that can be used in in Cerrado of Maranhão, to improve soybean yield and decrease the population of P. brachyurus. In this aspect, the objective of this study was to evaluate the effect of crop succession on the reduction of population and damage of $P$. brachyurus on soybean cultivated in the cerrado of Maranhão.

\section{Material and Methods}

The experiment was conducted in field conditions, from February 2016 to May 2017, with previous planting of the vegetation cover and subsequent planting of the soybean in the rainy season of February 2017. The experimental area was located at the Federal University of Maranhão, Brazil, Center of Agrarian and Environmental Sciences, in Chapadinha (MA) $\left(3^{\circ} 44^{\prime} 30^{\prime \prime}\right.$ S latitude and $43^{\circ} 21^{\prime} 37^{\prime \prime}$ WGR longitude, elevation 105 $\mathrm{m})$. The soil was classified as Dystrophic, Red-Yellow-Latosol, sandy texture $\left(160,40\right.$ and $800 \mathrm{~g} \mathrm{~kg}^{-1}$ of clay, silt and sand, respectively). The region has a subhumid, megahermic climate with great water deficiency in the summer (C2s2A'a'), annual rainfall ranging from 1600 to $2000 \mathrm{~mm}$, with rainfall unevenly distributed throughout the year.

The experimental design was a randomized block, with seven treatments and four replications. Treatments consisted in the following cropping systems: T1: cultivation of soybean as monoculture (control), T2: soybean cultivated in succession to "straw" of Crotalaria ochroleuca, T3: C. spectabilis + 'ADR 300' pearl millet, T4: 'ADR 300' pearl millet, T5: Brachiaria ruziziensis, T6: 'GNZ 2005' maize + B. ruziziensis and T7: 'GNZ 2005' maize. Plant species were sown in rows spaced $0.9 \mathrm{~m}$ (maize and maize + B. ruziziensis) or $0.225 \mathrm{~m}$ (other crops), in plots of $5 \times 8 \mathrm{~m}$.

In the intercropped system, the sowing of the cultures was simultaneous, with a line of B. ruziziensis in each interweave of the maize. In T3, the quantities of pure and viable seeds used were $10 \mathrm{~kg} \mathrm{ha}^{-1}$ for millet and $20 \mathrm{~kg}$ $\mathrm{ha}^{-1}$ for $C$. spectabilis, which were mixed and distributed in all seeding lines. The soybean cultivar used was 'Paragominas RR', with a population of 260,000 plants per hectare at a spacing of $0.5 \mathrm{~m}$ between lines.

For microbiological analysis, it was collected soil from each treatment and analyzed by the technique of centrifugal flotation in sucrose solution (Jenkins, 1964). For this, was extracted a $100 \mathrm{~cm}^{3}$ aliquot of soil into a vessel containing $2 \mathrm{~L}$ of water. After half filling with water, the mixture was well stirred and then allowed to stand for about $15 \mathrm{sec}$. before decanting through a 0.85 or $0.025 \mathrm{~mm}$. The residue on the sieve was collected in a beaker; the remaining soil was discarded. The residue was transferred to centrifuge tubes and spun for $5 \mathrm{~min}$. at about 1,750 r.p.m. Following centrifugation, the supernatant liquid was then poured off and a sugar solution added (454 g cane sugar/ $\mathrm{L}$ of water), thoroughly mixing sugar solution and sediment; the tubes are spun for 1 $\min$. The supernatant containing the nematodes was poured on to a $0.025 \mathrm{~mm}$ mesh sieve. The residue from this sieve was collected with the aid of water spray from a pissette to a becker. An aliquot obtained was placed in the Peters counting chamber and taken to the optical microscope to determine the population of P. brachyurus at 45 and 90 days after sowing.

In each period, the root systems of 10 soybean plants per plot were collected. The extraction of the nematodes present in the soybean roots was performed by the method of (Coole \& D'herde, 1972). The roots were cut into small pieces of $10 \mathrm{~g}$ for each sample, and then it was crushed for about $25 \mathrm{sec}$., in a blender containing $250 \mathrm{ml}$ of water. Soon after, the material was poured into 0.85 and $0.025 \mathrm{~mm}$ overlapping sieves. The $0.025 \mathrm{~mm}$ sieve residue was collected and distributed in centrifuge tubes, where $2 \mathrm{~g}$ of kaolin (stirred) were added to the tubes, 
which were equilibrated and centrifuged. From this step, the same procedures used to extract phytonematoids from the soil were followed.

The productivity of the crop, per plot, was evaluated in a useful area of $1 \times 1 \mathrm{~m}$ in $\left(1 \mathrm{~m}^{2}\right)$ and estimated in hectares. The following agronomic characteristics were evaluated: plant height, in centimeters - measured by the distance from the soil surface and the apex to the main stem; number of grains per plant—determined by the sum of grains per plant; number of pods per plant — obtained by the sum of all pods of the plant; number of grains per pod - determined by the ratio between the number of grains and the number of pods per plant; thousand grain mass - measured by weighing all the grains of the plant and estimating the mass of one thousand grains. It is important to note that the obtained mass was corrected for moisture of $13 \%$, and the data were transformed into $\mathrm{kg} \mathrm{ha}^{-1}$. Height measurement was performed in eight plants of each plot, randomly.

Data were submitted to analysis of variance by F-test (with significance level $p<0.05$ ) and comparison of means was performed using the Duncan test. The analyses were conducted using the statistical program InfoStat, 2016 version (Di Rienzo et al., 2016).

\section{Results and Discussion}

In Table 1, it is possible to observe the population dynamics of nematodes estimated in each treatment. There was a significant interaction between the management in the off-season and the time of collection of $P$. brachyurus.

The highest reductions of the populations of $P$. brachyurus were observed at 45 DAS, for the use of $C$. spectabilis + 'ADR 300' pearl millet and C. ochroleuca in the off-season. On the other hand, the cultivation of soybean on soybean and the use of 'GNZ 2005' maize in the off-season promoted an increase of $135.87 \%$ and $319.57 \%$, respectively, in the average population density of $P$. brachyurus in soybean roots, between 45 and 90 DAS (Table 1). In general, there was a lack of uniformity in the nematode population of soybean roots, under different management strategies in off-season, which shows that there is efficiency in the control of infestation through different cultural practices.

Table 1. Population densities of P. brachyurus in soybean roots, at 45 and 90 days after sowing, due to management in the soybean off-season

\begin{tabular}{llll}
\hline \multirow{2}{*}{ Off-season management } & \multicolumn{3}{c}{ Days after sowing } \\
\cline { 2 - 4 } & 45 & 90 & CV $(\%)$ \\
\hline Soybean (Control) & $793.75 \mathrm{Ab}$ & $1079.25 \mathrm{Aa}$ & 5.54 \\
Crotalaria ochroleuca & $182.25 \mathrm{Bb}$ & $327.25 \mathrm{Ca}$ & 24.77 \\
C. spectabilis + 'ADR 300' Pearl millet & $65.00 \mathrm{Ba}$ & $318.75 \mathrm{Ca}$ & 46.83 \\
'ADR 300' Pearl millet & $311.75 \mathrm{Ba}$ & $621.50 \mathrm{Ba}$ & 32.70 \\
Brachiaria ruziziensis & $235.50 \mathrm{Bb}$ & $602.00 \mathrm{Ba}$ & 17.12 \\
'GNZ 2005' Maize + B. ruziziensis & $203.25 \mathrm{Bb}$ & $815.25 \mathrm{Aa}$ & 45.23 \\
'GNZ 2005' Maize & $316.75 \mathrm{Bb}$ & $1012.25 \mathrm{Aa}$ & 24.76 \\
CV (\%) & 46.88 & 29.46 & \\
\hline
\end{tabular}

Note. Means followed by different letters in the lines (lower case) and columns (uppercase) differ at the $5 \%$ level of significance by the Duncan's test $(\mathrm{p}<0.05)$.

These results corroborate with those obtained by Leandro (2015) in the control of Rotylenchulus reniformis. in soybean planting on different cultural practices in off-season. However, it is important to emphasize that in the present study, the most effective treatments to reduce root infestation occurred with the use of crotalaria.

Concerning the infestation of P. brachyurus in the soil, it was observed that the control and the 'GNZ 2005' maize intercropped with B. ruziziensis, as well as their single farming in the off-season (T7), were the hosts of the largest populations of $P$. brachyurus in soil at 45 DAS and 90 DAS (Table 2). While the intercropped cultivation of $C$. spectabilis with pearl millet, and single crop of $C$. ohroleuca in the soybean off-season, were, in general, the most effective management strategies to reduce P. brachyurus population density in the soil.

According to Warnke et al. (2008) and Curto et al. (2015), the crotalaria are the main mechanism involved in phytonematodes suppression, because these plants have the capacity to act as traps, that is, they allow the penetration of these pathogens in their roots, in juvenile phases, however they prevent their subsequent 
development. Because in plants of this species there is the accumulation of secondary metabolites with nematicide action in the roots, as the monocrotaline in the roots, aerial parts and seeds (Wang et al., 2002; Colegate et al., 2012).

Table 2. Population densities of P. brachyurus at 45 and 90 days in $100 \mathrm{~cm}^{-3}$ of soil after sowing, due to management during the soybean off-season

\begin{tabular}{llc}
\hline \multirow{2}{*}{ Off-season management } & \multicolumn{1}{c}{ Days after sowing } \\
\cline { 2 - 3 } & $45 \mathrm{DAS}$ & $90 \mathrm{DAS}$ \\
\hline Soybean (Control) & $286 \mathrm{~b}$ & $1096 \mathrm{c}$ \\
Crotalaria ochroleuca & $132 \mathrm{a}$ & $500 \mathrm{ab}$ \\
C. spectabilis + 'ADR 300' Pearl millet & $130 \mathrm{a}$ & $377 \mathrm{a}$ \\
'ADR 300' Pearl millet & $170 \mathrm{ab}$ & $722 \mathrm{abc}$ \\
Brachiaria ruziziensis & $175 \mathrm{ab}$ & $807 \mathrm{abc}$ \\
'GNZ 2005' Maize + B. ruziziensis & $195 \mathrm{ab}$ & $1012 \mathrm{abc}$ \\
'GNZ 2005' Maize & $275 \mathrm{~b}$ & $1067 \mathrm{bc}$ \\
CV (\%) & 40.77 & 43.50 \\
\hline
\end{tabular}

Note. Means followed by different letters differ at the $5 \%$ level of significance by the Duncan's test $(\mathrm{p}<0.05)$.

Therefore, the cultural management practices in the soybean off-season may imply a greater or less tolerance of the culture to P. brachyurus. In general, the use of grasses such as maize, pearl millet, Brachiaria, in the soybean off-season, leads to the estimation of greater infestations of P. brachyurus, both in soil and in roots, especially in sandy soils with low water retention capacity, as used in the present study and evidenced in most of the commercial areas of soybean in the East of Maranhão.

In this aspect, it is important that the use of a grass, such as 'ADR 300' pearl millet, which presents high potential of shoot biomass production (Soratto et al., 2012), is strategically conducted in a consortium with crotalaria, such as $C$. spectabilis. This may allow the increase of the soil cover, and especially the reduction $P$. brachyurus population, with greater guarantee of better yields of the soybean, in succession, in the cerrado of Maranhão.

The soybean crop increase, submitted to different management strategies in the off-season, was monitored by the estimation of plant height in different evaluation periods. There was a significant difference in plant height, both on the influence of soil cover treatments and on the four evaluation periods, and their respective interactions.

The use of 'GNZ 2005' maize with B. ruziziensis in the off-season promoted the highest average growth and was, therefore, significantly higher than other treatments (Table 3). Although this treatment allowed high infestation of $P$. brachyurus in soil and soybean roots, compared to the others, there was good vegetative growth of the crop. Probably, this was due to the quantity and quality of the straw made by these treatments, in succession with the soybean, which culminates in positive results in the short term.

Table 3. Soybean plants height (Paragominas RR) due to management during the off-season

\begin{tabular}{llllll}
\hline \multirow{2}{*}{ Off-season management } & \multicolumn{5}{c}{ Days after sowing } \\
\cline { 2 - 6 } & 42 & 50 & 57 & 65 & \\
\hline Soybean (Control) & $27.34 \mathrm{Ba}$ & $32.91 \mathrm{Bb}$ & $44.38 \mathrm{Ac}$ & $50.72 \mathrm{Abc}$ & 6.59 \\
Crotalaria ochroleuca & $28.31 \mathrm{Ba}$ & $34.00 \mathrm{Bab}$ & $46.00 \mathrm{Ac}$ & $49.97 \mathrm{Abc}$ & 10.63 \\
C. spectabilis + 'ADR 300' Pearl millet & $29.22 \mathrm{Ba}$ & $37.03 \mathrm{Bab}$ & $49.91 \mathrm{Abc}$ & $51.75 \mathrm{Abc}$ & 2.89 \\
'ADR 300' Pearl millet & $27.84 \mathrm{Ca}$ & $33.78 \mathrm{BCab}$ & $42.72 \mathrm{ABc}$ & $44.97 \mathrm{Ac}$ & 4.07 \\
Brachiaria ruziziensis & $32.84 \mathrm{Ba}$ & $41.03 \mathrm{Bab}$ & $57.59 \mathrm{Aab}$ & $58.72 \mathrm{Ab}$ & 11.55 \\
'GNZ 2005' Maize + B. ruziziensis & $35.16 \mathrm{Ba}$ & $43.50 \mathrm{Ba}$ & $66.19 \mathrm{Aa}$ & $69.44 \mathrm{Aa}$ & 8.46 \\
'GNZ 2005' Maize & $28.16 \mathrm{Ba}$ & $35.16 \mathrm{Bab}$ & $48.41 \mathrm{Abc}$ & $56.66 \mathrm{Ab}$ & 7.52 \\
CV (\%) & 8.67 & 12.85 & 15.52 & 16.65 & \\
\hline
\end{tabular}

Note. Means followed by different letters in the lines (lower case) and columns (upper case) differ at the $5 \%$ level of significance by the Duncan's test $(\mathrm{p}<0.05)$. 
It is important to note that treatments with single and intercropped crotalaria, although they were effective in reducing the infestation of $P$. brachyurus in the soil and soybean roots, presented intermediate height results (Table 3). This may be due to the low soil cover promoted by the crotalaria species used (Costa et al., 2014; Soratto et al., 2012) and by the rapid decomposition of soil cover from pearl millet (Dias et al., 2010). This obstacle has been one of the negative points for the use of pearl millet in succession with the soybean in the cerrado of Maranhão, that in its edaphoclimatic conditions favor a rapid decomposition of the straw.

The monoculture of the soybean (control) culminated in low vegetative growth, possibly due to the high susceptibility to $P$. brachyurus and the almost nullity of straw in the monoculture conditions analyzed, which interferes with the water use efficiency, nutrition and health of the crop main.

It is worth mentioning that plant height, as well as the insertion of soybean pods, is determined by the genetics of the variety, being influenced by conditions such as soil fertility, climate, sowing season and latitude (Meotti et al., 2012).

Soybean yield was higher in the cultivation on straw of 'GNZ 2005' maize, with a significant difference compared to the other treatments. In the treatment of 'GNZ 2005' maize + B. ruziziensis, the average of the soybean yield was superior to the soybean management in monoculture (control), but without significant difference among them at the level of $5 \%$ of significance presented in (Table 4 ).

Table 4. Soybean Productivity (Paragominas RR), due to the management during the off-season

\begin{tabular}{ll}
\hline Off-season management & Days after sowing $\left(\mathrm{kg} \mathrm{ha}^{-1}\right)$ \\
\hline Soybean (Control) & $2.411,11 \mathrm{ab}$ \\
Crotalaria ochroleuca & $1.873,81 \mathrm{~b}$ \\
C. spectabilis + 'ADR 300' Pearl millet & $2.194,19 \mathrm{~b}$ \\
'ADR 300' Pearl millet & $1.943,81 \mathrm{~b}$ \\
Brachiaria ruziziensis & $2.186,25 \mathrm{~b}$ \\
'GNZ 2005' Maize + B. ruziziensis & $2.419,03 \mathrm{ab}$ \\
'GNZ 2005' Maize & $2.853,44 \mathrm{a}$ \\
CV (\%) & 19.31 \\
\hline
\end{tabular}

Note. Means followed by different letters differ at the $5 \%$ level of significance by the Duncan's test $(\mathrm{p}<0.05)$.

Productivity oscillated from $1.873,81$ and $2.853,44 \mathrm{~kg} \mathrm{ha}^{-1}$ for a coefficient of variation estimate of $19.31 \%$. The best result was obtained with the use of 'GNZ 2005' maize, in the soybean off-season, and is in line with the average productivity estimated by CONAB (2017) for soybean cultivation in the cerrado of Maranhão.

Although it allowed a greater infestation of P. brachyurus, both in soil and in soybean roots, the beneficial effects of maize straw were effective in the short term. However, it is important to consider the characteristic of this culture as host of $P$. brachyurus, which is one of the main phytosanitary problems faced by the producers of Baixo Parnaíba Maranhense. This may induce increased of P. brachyurus infestation in the medium and long term.

Due to the economic importance of maize and soybean growth and productivity increases, in succession management with this crop, it is necessary to analyze the maize intercropping with crotalaria, which are important cultural nematicides, or test other maize cultivars, with lower susceptibility to $P$. brachyurus.

Regarding the results obtained for the maize and B. ruziziensis intercropping and soybean in monoculture, it is important to highlight the infestation of $P$. brachyurus destined for these systems, with consequent long-term phytosanitary risks, which may cause drastic negative effects on yield of the soybean crop in the cerrado of Maranhão.

Although widely used by local farmers, pearl millet in succession has not been shown effective in increasing soybean growth and yield. Possibly, due to the low $\mathrm{C} / \mathrm{N}$ ratio of the straw, which presents quickly decomposition in the soil and climatic conditions of the cerrado of Maranhão, in off-season.

Although the species of crotalaria analyzed were effective nematicides, did not induce a good yield of the soybean. This was probably due to the low supply of straw to the soil. However, it is essential to study the effect of other crotalaria species, as well as to intercrop them with other crops that are economically important in the 
local market, such as maize. But, it is preponderant that this system of succession is, moreover, efficient in the improvement of the straw and yield of the soybean.

For the other agronomic characteristics of the soybean (Table 5), there was no significant effect of the evaluated treatments. These results corroborate with those found by several authors (Chioderoli et al., 2012; Lima et al., 2009; Nunes et al., 2010). Possibly, this can be attributed to the genetics of the cultivar analyzed.

Table 5. Agronomic characteristics of soybean cv. Paragominas RR, due to the management during the off-season in the cerrado of Maranhão

\begin{tabular}{lllllllll}
\hline \multirow{2}{*}{ Off-season management } & \multicolumn{9}{c}{ Variables } \\
\cline { 2 - 8 } & NP & NPo & NPoP & NGPo & NGP & NG & MTG & DM \\
\hline Soybean (Control) & 34.00 & 1136.3 & 33.74 & 2.10 & 70.21 & 2367.3 & 98.90 & 209.8 \\
Crotalaria ochroleuca & 33.75 & 919.25 & 27.91 & 1.96 & 55.33 & 1816.8 & 98.28 & 185.6 \\
C. spectabilis + 'ADR 300' Pearl millet & 38.25 & 1163 & 31.13 & 1.86 & 5.50 & 2166.0 & 94.08 & 257.8 \\
'ADR 300' Pearl millet & 35.00 & 1203.5 & 33.89 & 2.01 & 68.12 & 2418.3 & 95.10 & 277.6 \\
Brachiaria ruziziensis & 47.00 & 1172.5 & 26.47 & 2.03 & 54.23 & 2366.8 & 100.6 & 333.4 \\
'GNZ 2005' Maize + B. ruziziensis & 49.75 & 1340.3 & 26.42 & 2.00 & 53.06 & 2695.3 & 92.60 & 290.6 \\
'GNZ 2005' Maize & 43.75 & 1364.3 & 33.58 & 2.02 & 70.38 & 2789.5 & 96.20 & 338.4 \\
-CV (\%) & 27.00 & 28.09 & 27.43 & 8.85 & 31.56 & 30.86 & 6.67 & 40.47 \\
\hline
\end{tabular}

Note. NP: number of plants; NPo: number of pods per $\mathrm{m}^{2}$; NPoP: number of pods per plant; NG: number of grains; NGP: number of grains per plant NGPo: number of grains per pod; MTG: mass of a thousand grains and DM: dry matter.

\section{Conclusions}

Crotalaria spectabilis and Crotalaria ochroleuca were effective in reducing P. brachyurus infestation in soil and soybean roots in succession. However, it is important to combine these legumes with grasses or other straw-growing crops into the system in order to obtain better yields of soybean growth and productivity.

'GNZ 2005' maize and Brachiaria ruziziensis were important for increasing soybean yield in succession, however, the prolonged use of these species may increase the risks with phytosanitary problems associated with P. brachyurus in the cerrado of Maranhão.

\section{References}

Barbosa, B. F. F., dos Santos, J. M. D., Barbosa, J. C., Soares, P. L. M., Ruas, R. A., \& Carvalho, R. B. (2013). Agressividade de Pratylenchus brachyurus à cana-de-açúcar, em comparação com o nematoide $P$. zeae. Nematropica, 43(1), 119-130.

Chioderoli, C. A., Mello, L. M., Grigolli, P. J., Furlani, C. E., Silva, J. O., \& Cesarin, A. L. (2012) Atributos físicos do solo e produtividade de soja em sistema de consórcio milho e braquiária. Revista Brasileira Engenharia Agricola e Ambiental, 16(1), 37-43. https://doi.org/10.1590/S1415-43662012000100005

Colegate, S. M., Gardner, D. R., Joy, R. J., Betz, J. M., \& Panter, K. E. (2012). Dehydropyrrolizidine alkaloids, including monoesters with an unusual esterifying acid, from cultivated Crotalaria juncea (Sunn Hemp cv.'Tropic Sun'). J Agric and Food Chemistry, 60(14), 3541-3550. https://doi.org/10.1021/jf205296s

CONAB (Companhia Nacional de Abastecimento). (2017). Acompanhamento da safra brasileira. Grãos 2017/2017: Décimo segundo levantamento. Retrieved from http://www.conab.gov.br

Coolen, W. A., \& D'Herde, C. J. (1972). A method for the quantitative extraction of nematodes from plant tissue (p. 77). Ministry of Agriculture of Belgium, Agri Research Administration.

Costa, M. J. N., Pasqualli, R. M., \& Prevedello, R. (2014). Efeito do teor de matéria orgânica do solo, cultura de cobertura e sistema de plantio no controle de Pratylenchus brachyurus em soja. Summa Phytopathologica, 40(1), 63-70. https://doi.org/10.1590/S0100-54052014000100009

Curto, G., Dallavalle, E., Santi, R., Casadei, N., D’Avino, L., \& Lazzeri, L. (2015). The potential of Crotalaria juncea L. as a summer green manure crop in comparison to Brassicaceae catch crops for management of Meloidogyne incognita in the Mediterranean area. Eur J Plant Pathology, 142(4), 829-841. https://doi.org/ $10.1007 / \mathrm{s} 10658-015-0655-2$ 
Franchini, J. C., Debiasi, H., DIAS, W. P., Ramos, J. E. U., \& Silva, J. F. V. (2014). Perda de produtividade da soja em área infestada por nematoide das lesões radiculares na região médio norte do Mato Grosso. In A. C. Bernardi, J. de M. Naime, A. V. Resende, L. H. Bassoi, \& R. Y. Inamasu (Eds.), Agricultura de precisão: resultados de um novo olhar (pp. 274-278). Brasília: Embrapa.

Freitas, J. R. B., Moitinho, M. R., de Bortoli, T. D., da Silva, B. E., da Silva, J. F., Siqueira, D. S., \& Pereira, G. T. (2017). Soil factors influencing nematode spatial variability in soybean. Jornal Agronomy, 109(2), 610-619. https://doi.org/10.2134/agronj2016.03.0160

Goulart, A. M. C. (2008). Aspectos gerais sobre nematoides-das-lesões-radiculares (gênero Pratylenchus). Planaltina: Embrapa Cerrados.

Goulart, M. M. P., do Carmo, E. L., Santos, C. B., dos Santos, V. R., \& Campos, H. D. (2013). Avaliação do efeito de diferentes populações de Pratylenchus brachyurus na cultura da soja. Global Sci and Tech, 6(2), 08-14. https://doi.org/10.14688/1984-3801.v06n02a01

Haegeman, A., Mantelin, S., Jones, J. T., \& Gheysen, G. (2012). Functional roles of effectors of plant-parasitic nematodes. Gene, 492(1), 19-31. https://doi.org/10.1016/j.gene.2011.10.040

Inomoto, M. M., (2011). Avaliação da resistência de 12 híbridos de milho a Pratylenchus brachyurus. Trop Plant Pathology, 36(5), 308-312.

Jenkins, W. (1964). A rapid centrifugal-flotation technique for separating nematodes from soil. Plant Disease Repórter, 48(4), 692.

Leandro, H. M., \& Lafourcade, A. G., (2015). Rotação e sucessão de culturas para o manejo do nematoide reniforme em área de produção de soja. Ciência Rural, 45(6), 945-950. https://doi.org/10.1590/0103-8478cr 20130526

Lima, E. D. V., Crusciol. C. A. C., Cavariani, C., \& Nakagawa J. (2009). Características agronômicas, produtividade e qualidade fisiológica da soja safrinha sob semeadura direta, em função da cobertura vegetal e da calagem superficial. Revista Brasileira de Sementes, 31(1), 69-80. https://doi.org/10.1590/S010131222009000100008

Machado, A. C., Motta, L. C., de Siqueira, K. M., Ferraz, L. C., \& Inomoto, M. M. (2007). Host status of green manures for two isolates of Pratylenchus brachyurus in Brazil. Nematology, 9(6), 799-805. https://doi.org/ $10.1163 / 156854107782331153$

Meotti, G. V., Benin, G., Silva, R. R., Beche, E., \& Munaro, L. B. (2012). Épocas de semeadura e desempenho agronômico de cultivares de soja. Pesquisa Agropecuária Brasileira, 47(1), 14-21. https://doi.org/ 10.1590/S0100-204X2012000100003

Nunes, A. S., Timossi, P. C., Pavani, M. C., \& Costa, A. P. L. (2010). Formação de cobertura vegetal e manejo de plantas daninhas na cultura da soja em sistema plantio direto. Planta Daninha, 48(3), 727-733. https://doi.org/10.1590/S0100-83582010000400004

Queiróz, C. D. A., Fernandes, C. D., Verzignassi, J. R., Valle, C. B. D., Jank, L., Mallmann, G., \& Batista, M. V. (2014). Reaction of accessions and cultivars of Brachiaria spp. and Panicum maximum to Pratylenchus brachyurus. Summa Phytopathologica, 40(3), 226-230. https://doi.org/10.1590/0100-5405/1899

Soratto, R. P., Crusciol, C. A. C., Costa, C. H. M. D., Ferrari, N. J., \& Castro, G. S. A. (2012). Produção, decomposição e ciclagem de nutrientes em resíduos de crotalária e milheto, cultivados solteiros e consorciados. Pesquisa Agropecuária Brasileira, 47(10), 1462-1470. https://doi.org/10.1590/S0100-204X 2012001000008

Tacaoca, M. C., Freitas, L. A. J., Lazarini, E., Rebuá, R. L., \& Guilhien, G. J. F. (2005). Manejo de espécies vegetais de cobertura de solo e produtividade do milho e da soja em semeadura direta. Acta Scientiarum. Agronomy, 27(2), 199-207.

Thornthwaite, C. W. (1948). An approach toward a rational classification of climate. Geographical Review, 38(1), 55-94. https://doi.org/10.2307/210739

Vilela, L., Junior, G. B. M., Macedo, M. C. M., Marchão, R. L., Júnior, R. G., Pulrolnik, K., \& Maciel, G. A. (2012). Sistemas de integração lavoura-pecuária na região do Cerrado. Pesquisa agropecuária Brasileira, 46(10), 1127-1138. https://doi.org/10.1590/S0100-204X2011001000003

Wang, K. H., Sipes, B. S., \& Schmitt, D. P. (2002). Crotalaria as a cover crop for nematode management: A review. Nematropica, 32(1), 35-57. 
Warnke, S. A., Chen, S., Wyse, D. L., Johnson, G. A., \& Porter, P. M. (2008). Effect of rotation crops on hatch, viability and development of Heterodera glycines. Nematology, 10(6), 869-882. https://doi.org/10.1163/ 156854108786161391

\section{Copyrights}

Copyright for this article is retained by the author(s), with first publication rights granted to the journal.

This is an open-access article distributed under the terms and conditions of the Creative Commons Attribution license (http://creativecommons.org/licenses/by/4.0/). 